\title{
IDEAS ABOUT NATIONAL IDENTITY IN RUSSIAN LITERARY REVIEW, HISTORICAL AND LITERARY DISCOURSES OF THE 19TH - EARLY 20TH CENTURY
}

\author{
Viacheslav Krylov ${ }^{1}$
}

\begin{abstract}
This article analyses the evolution of literary reflections among the representatives of the 19th-early 20th-century trends and schools where ideas on national literature distinctness were formed. The study specifies both an invariant of the notions of national literature identity and individual variations that did not find further development in literary selfawareness. The essays of the 1870-80s suggest that there was formed an image of the original literature opposed to European literature. A new impetus to the problem of national identity in literature was attached to the era of the Silver Age; however, the analysis of the literary review, historical and literary discourses of the turn of the century leads to the conclusion that it was in this era that the ideology of literary centrism was further strengthened, and the exclusive status of Russian literature in culture received detailed reflection.
\end{abstract}

UDC Classification: 821.161.1; DOI: http://dx.doi.org/10.12955/cbup.v5.1007

Keywords: national identity, Russian, literary centrism, discourse.

\section{Introduction}

There exist well-known ideas made by foreign writers and researchers about the national originality of Russian literature. However, the study of a national identity requires a view made by the natives since the concept of identity presupposes a stable self-image developed in self-reflection and introspection. According to the British researchers Simon Franklin and Emma Uiddis, ideas about Russia and Russian... to a great extent are the fruit of those who can be called "the producers of culture" "in the broadest sense of the word" (Franklin and Uiddis, 2014). They also stated that a significant part of Russian culture, either directly or indirectly, to a greater or lesser degree, is addressed to itself and is permeated with the theme of Russia and Russianness (Franklin and Uiddis, 2014). Russian criticism, journalism, and the history of literature exist as a feature of culture in which the Russian theme is constantly discussed and dreamed of.

One of the forms of literary self-consciousness is criticism, especially the critical and aesthetic texts of the writers themselves, their declarations and manifestos. The ideas developed in them about Russian literature as a holistic phenomenon, its specific features, and national identity have undergone a long evolution - from the Romantics - Pushkin, Gogol, I. Aksakov, to the Symbolists - S. Vengerov and others.

The aim of this article is to present a comparative analysis of reflections on literary reviews of representatives of different trends and schools of the $19^{\text {th }}$-early $20^{\text {th }}$ century, during which the construction of ideas about the national originality of literature was carried out. The materials and results of the research can be used in teaching the history of Russian literature. They also contribute to the study of the issues of national identity in Russian culture. In the course of the study, new questions arose related to the study of the fate of the literary-centrist ideology in the Soviet and post-Soviet epochs.

\section{Data and Methodology}

In recent decades, the topic of national self-identification, the study of the mythology and the ideology of imperial consciousness, their reflection in various cultural practices have been of interest in contemporary humanities. One of the latest issues of the independent Russian journal Novoe literaturnoe obozrenie was devoted to the theme "The Imperial Imagination and Cultural Policies". The editorial staff rightly proceeded from the premise that "cultural texts and cultural sources can sometimes tell us more about imperial ambitions and fantasies than the openly declared political projects" (Prokhorova, 2017). Many researchers turn for the reconstruction of national identity to the texts of fiction, but even today literary review, historical and literary discourses are still on the periphery of the research interest. The basis of our research is the methodological idea that literary criticism is not only a reflection on literature, but also a discussion about the social structure of society, psychological problems; it is a way for a person to take a closer look at life. The concepts

\footnotetext{
${ }^{1}$ Kazan (Volga Region) Federal University, krylov77@list.ru
} 
introduced by Wilde (1966), Frye (1973), Hartman (1980), and Man (1983) influenced our understanding of the literary review discourse.

\section{Results and Discussion}

The experience of German aesthetics was of great importance for Russian literature, including the impact of understanding of the nation and national identity that goes back to Herder and the German Romantics.

The topic of national identity dates back to the era of Romanticism. From the standpoint of the aesthetics of Classicism, this or that national manifestation in literature was recognized as an unauthorized deviation from the universal human norm which rested on rational grounds. But the preRomantics raised the topic much earlier. Here is an example of the opening of A. Turgenev's "Speech on Russian Literature" read in "The Friendly Literary Society" in March 1801, "On Russian Literature! Can we use this word? Can it be an insignificant notion for something that does not exist?" (Turgenev, 1980). Following A. Turgenev, the famous slogan of the Russian Romantics "We have no literature" was developed by V. Kiukhelbeker, A. Bestuzhev, D. Venevitinov, A. Pushkin, and early Belinsky. All of them blamed the contemporary literature for imitation, reckless following of patterns, and oblivion of national identity. It should be noted that it triggered the mechanism of diachronic excluding of certain texts from the literature that Yu. Lotman wrote about: "Exclusion of certain texts from literature occurs not only synchronically but also diachronically; the texts written before the appearance of the declared norms or not related to them are considered non-literature" (Lotman, 1992).

D. Venevitinov in his article "On Enlightenment in Russia" (1826) argued that Russia had received everything from the outside; this concerned the feeling of imitation, complete absence of any freedom and true activity. He called the position of Russia in the literary world as "completely negative" (Venevitinov, 1980).

Romantic treatises were created in the rhetoric of the expected future, anticipation, passionate expectation of the original Russian literature. Romantics reasoned to a greater extent that we could have a truly folk poetry.

The most important Russian romantic treatise "On Romantic Poetry" by O. Somov begins with a typically romantic thesis: "Literature of every nation is a self-explanatory picture of its customs, traditions and a way of life. Every writer, as if involuntarily, displays folk features. Thus, it is almost possible to guess the composition of a German, an Englishman or a Frenchman, at least in translation". (Somov, 1974). Somov argued that the properties of poetry depended on the "spirit of the language," "inclinations and customs of the people," properties of the surrounding objects. (Somov, 1974). In Russia, there are all conditions for a truly original literature, free from imitations.

In this respect, the evolution of Belinsky's views on the specifics of Russian literature is indicative. There is good reason why his first significant work was titled "Literary Dreams." Here Belinsky also noted the absence of Russian literature. Having put forward the thesis, Belinsky at the same time was full of confidence in the emergence of original literature:

"We have no literature. I repeat this with delight, with pleasure, for in this truth I see a pledge of our future successes. Take a good look at the course of our society, and you will agree that I am right" (Belinsky, 1948a).

Six years later, in the review "Russian Literature in 1840", while reviewing the question of lack of literature in Russia, Belinsky argued, "The source of literature of the people may not be some external impulse or an external push, but only a world outlook of the people" (Belinsky, 1948b). According to Belinsky, Russian literature started with Pushkin - "this is not Russia's acquaintance with Europe, but Europe's with Russia" (Belinsky, 1948a).

The article "The general Meaning of the Word Literature" displayed a change of the tone of the assessment. European influence on Russian literature was interpreted by him from the standpoint of special properties of the Russian character (NB: long before Dostoevsky!).And in the review "Russian Literature in 1842" (after the publishing of "The Dead Souls"), he definitely said, "Our social life is predominantly expressed in literature" (Belinsky, 1948b). Literature strengthened "on the basis of 
Russian nationality, entered the life of society" (Belinsky, 1948b). Thus, one can conclude that Belinsky was one of the first to state the fact of literary centrism in Russian culture.

Revealing the influence of literature on society, Belinsky noted:

"Our literature has created the morals of our society, raised several generations, and formed a kind of public opinion" (Belinsky, 1948c).

It was then that the tradition of criticism to determine not only the content properties of Russian literature but its enhanced functional role in society too was introduced. Henceforth, most of the discourses on Russian literature were created within the literary-centric focus. Rare voices of a different position do not change the general picture, but they cannot be ignored.

Thus, I. Aksakov, in his article "On the Exaggerated Significance Attached by Us to the Action of Literature", expressed, contrary to the general opinion, an unexpected thought, "...because of our abnormal social development, literature does not mean what it must mean to us, it is forced by circumstances to play a role that is not characteristic for it, and, in fact, illegal. In all other educated countries, literature is one of many organs by which the actions of the social organism are committed" (Aksakov, 2006). This is no longer a recognition of merits, as Belinsky did; an exaggerated significance of literature is a "wild anomaly" (Aksakov, 2006).

The Slavophil discourse excluded a positive influence of such literature on society, the tyrannical power of literature was an imaginary power. This trend was continued in the early $20^{\text {th }}$ century. The reasoning of I. Aksakov is attributed to those peripheral voices, which were destined to manifest later.

But on the whole, the arguments about Russian literature since the 1840s were built in the rhetoric of what was accomplished, albeit with constant reservations about the "youth" of Russian literature. M. Alekseev wrote, "A few decades later everything that Belinsky dreamed about and believed in became a real fact and was fully realized. A friend and pupil of Belinsky, I. Turgenev, acquired the panEuropean significance, Herzen's voice sounded throughout Europe and in all European languages, he was followed by Leo Tolstoy and Dostoevsky who received worldwide recognition". (Alekseev, 1976).

Starting with the 1870s and 1880s, when Russian literature gained recognition in Europe, critical discourses were based on the juxtaposition of Russian and European literatures. Here, first of all, it is necessary to name the speeches of I. Turgenev (June 1878, Paris, The International Literary Congress) and S. Vengerov. In these arguments, there was constructed an image of original literature that exerted an immeasurably greater influence on Russian society than in European countries.

Returning to the logic of criticism of the 1870s-80s, one can note that it always strived to raise Russian literature. Academician M. Alekseev drew attention to the storm of indignation caused by Turgenev's speech at the Paris Congress among all Russian writers and in the Russian press, "Why did, according to Turgenev's critics, he chose such criterion for the value of Russian literature as its proximity to European models?" (Alekseev, 1976).

At the same time there appeared arguments about the originality of the form of Russian literature expressed in the writer's own environment. For example, L. Tolstoy's article "A Few Words About the Book "War and Peace" (1868).

In the late $19^{\text {th }}$ - early $20^{\text {th }}$ centuries the problem acquired a new impulse: there was an aspiration to integrate, give results of the literary development of the entire $19^{\text {th }}$ century - the "golden" century of Russian literature, during which the language, forms, and the content of literature changed so much and its influence on Russian society changed radically.

During this period, we can speak of two positions in relation to literary centrism, of the coexistence of two, to a certain extent, oppositional ideologies. One ideology appealed to literary centrism as the core property of Russian culture and even, despite its crisis, sought to "preserve," that is to keep the special status of literature.

A literary historian Petr Morozov in a little-known essay "Russian Literature in the $19^{\text {th }}$ Century" (1902) outlined the path of new Russian literature from the time of its apprenticeship and imitation to independence. Russian literary heritage of the $19^{\text {th }}$ century was contrasted here with the decline of the ast decade. "Our literature has always set itself the goal of life teaching - to help a thinking reader in their quest to understand the surrounding life." (Morozov, 1902). 
According to Morozov, at a time when Russian literature acquired national identity and gained world recognition, modern literature began to decline, "our literature was constantly losing the thread of its once organic development; new writers do not know whether to continue Turgenev and Tolstoy or follow Zol's footsteps, or imitate Ibsen, or transplant the rotten shoots of French decadence into the Russian soil" (Morozov, 1902), that is, its identity is lost.

Other less prominent voices (although their number increased in the Silver Age) talked of "moving" literature to a normal, equal place among all literature in a broad sense (here you can see the continuation of I. Aksakov's point of view).

In a little-known article by Nikolai Shapir with an indicative title "Literature Teaching" published in the journal "Russian Thought" (1913, no. 4), a special public role of literature in Russia became a reflection of the low intensity of the national culture. (Shapir, 1913).

"It is necessary to put literature on a par with all other books" (Morozov, 1902).

In this regard, the attitude of critics to contemporary literature changed. For some, as has already been shown at the example of Morozov's work, Russian literature finally acquired a national status, but it lost its identity. Others saw in the contemporaries' attempt to "teach" (Gorky and others) a step back.

Lev Shestov, defining the distinctive properties of Russian literature ("simplicity, truthfulness, and perfect absence of rhetorical embellishments"), saw in them "a consequence of our relative lack of culture" (Shestov, 1996). In the book "The Apotheosis of Groundlessness" (part 2, Chapter 45), he contrasted Western European and Russian people, which, according to Shestov, also influenced the writer's behaviour, "A European person relies only on themselves and nobody else. They firmly believe that if they do not help themselves, then no one will help them. Accordingly, all their thoughts are directed to the best possible arrangement of their life... Russian writers, with few exceptions, quite sincerely despise the pettiness of the West". (Shestov, 1996).

Perhaps the most serious blow to the literary-centred ideology was inflicted by V. Rozanov in his late articles of 1917-18 in which he drew an almost apocalyptic image of the entire country's demise from literature. He, in fact, made Russian literature the culprit of the Russian revolution. (Rozanov, 1995).

But, despite these tendencies of revision of the existing paradigm, the literary-centric discourse still prevailed in the Silver Age in judgments both of symbolist and religious and philosophical criticism, and the trend of "pushing back" literature remained on the periphery of public consciousness.

Russian symbolism from the late 1900s, having acquired a neo-Slavophile orientation, was also in this paradigm. A significant place in Andrei Beliy's article "The Present and Future of Russian Literature" (1909) occupied a comparative characterization of Russian and Western European literature (as already noted, the Russian discourse on literature in the $19^{\text {th }}$ century rarely touched upon meaningful characteristics), "The task of contemporary Russian literature is to accept the provision of Western European aesthetics: the form is inseparable from the content. But Russian literature will never agree to such a conclusion. A form is only a product of religious creativity. A literary device is the outward expression of a living confession". (Beliy, 1994).

Therefore, we can see that the literary-centric discourse of the early $20^{\text {th }}$ century appealed to the past; it was filled with the memory of the tops of the $19^{\text {th }}$ century.

A kind of final historical and literary reflection on Russian literature was Semyon Vengerov's presentation "What Is the Charm of Russian Literature of the $19^{\text {th }}$ century?" (The speech was delivered in Moscow on October 22, 1911 at the celebration of the centennial anniversary of the Society of Lovers of Russian Literature.). S. Vengerov dwelled on the question: what is actually Russian literature. He did not follow the path of functional definitions of literature, but tried in a capacious but expressive form to define its key meaningful constants. To determine the essence of Russian literature, Vengerov used the term "suggestion" introduced by J. Guyot referring it to the word "charm." This, according to Vengerov, was "the only key to understand Russian literature in particular" (Vengerov, 1919).

Russian literature, according to Vengerov, was created remarkably by a "conscience-stricken gentleman." Developing the populist argument, Vengerov saw it in the "conscience-stricken gentleman" as the main source of its "charm and spell." And even for the unprivileged intellectual who succeeded him in the $60 \mathrm{~s}$ "the problem of conscience, the problem of subjugating the personal good to 
the common good proved to be... as burning as for the "conscience-stricken gentleman." (Vengerov, 1919).

Reconstructing the model of life in Russian literature, the type of thinking reflected in it, behavior and attitude toward life Vengerov argued that in Russian literature "the ideal of personal happiness is completely banished." "Personal happiness in the understanding of Russian literature is either criminal, if it is created at the expense of others, or, at best, is vulgar. The fact was striking and at the same time profoundly touching, profoundly significant for the establishment of the heroic character of the $19^{\text {th }}$-century Russian literature: there is no Russian novel, no Russian story written by a real coryphaeus with the so-called happy denouement which was typical of European literature and firstclass writers". (Vengerov, 1919).

This ethical orientation of Russian literature created a special emotional pathos: "Hence another source of fascination of the $19^{\text {th }}$-century Russian literature is what I call Great Sorrow. It seems to me that this Great Sorrow, spilled all over new Russian literature, is in close organic connection with the entire Russian national character. Russian landscape is sad, which, however, Nekrasov so yearned for among the luxurious nature of the south. A Russian song is sad, "like a moan," by the definition of the same Nekrasov... But the sadness carries unspeakable beauty. Carefree and cheerful laughter is completely alien to Russian literature. It knows only bitter laughter". (Vengerov, 1919).

\section{Conclusion}

Thus, we examined in the diachronic aspect a set of ideas of Russian writers about themselves at different stages in the development of literature. The study specifies both an invariant of the notions of national literature identity and individual variations that did not find further development in literary self-awareness. The starting point of the formation of Russian literature uniqueness is attributed to the pre-Romanticism. Necessity for original Russian literature inspired A. Turgenev to claim that Russian originality should manifest itself, first of all, in the surrounding life free from uncritical borrowing. Following A. Turgenev, the idea of denying truly national literature in Russia became a trend and was continued in the speeches of Kiichelbecker, Bestuzhev, Venevitinov, Pushkin, and early Belinsky. A symbolic expression of this idea is the formula "We have no literature." Most romantic treatises were written in the rhetoric of the expected future. Belinsky's articles occupy a special place in the formation of ideas on national literature originality. Besides, his early works resemble the findings of romantic aesthetics. However, after reviewing Russian literature of the 1840 s, we can say that he linked the history of literature with the world outlook of the people. Belinsky was one of the first to note the tendency for emerging literary centrism in Russian culture. Starting with Belinsky, most of the critical, historical and literary discourses about Russian literature were created with the focus on literature.

The article highlights two opposing ideologies based on the essays of the critics of the late $19^{\text {th }}$-early $20^{\text {th }}$ century. One of them appealed to literary centrism, but the number of those critics who talked about the artificiality of such a situation increased. Nevertheless, the ideology of literary centrism remained predominant. The fate of these views in the Soviet and post-Soviet eras may be the topic of a separate study.

\section{References}

Aksakov, I. S. (2006). U Rossii odna-edinstvennaia stolitsa. [Russia Has Only One Capital], Moscow, Russkii mir

Alekseev, M. P. (1976). Russkaia klassicheskaia literatura i ee mirovoe znachenie, Russkaya literature, No 1, 6-33 [Russian Classical Literature and its World Significance, Russian literature, 1, 6-33]

Belinsky, V. G. (1948a) Sobranie sochinenii v 3-kh tomakh. [Collection of works in 3 volumes] Tom 1, Moscow, OGIZ.

Belinsky, V. G. (1948b) Sobranie sochinenii v 3-kh tomakh. [Collection of works in 3 volumes] Tom 2., Moscow, OGIZ

Belinsky, V. G. (1948c) Sobranie sochinenii v 3-kh tomakh. [Collection of works in 3 volumes] Tom 3, Moscow, OGIZ

Beliy, A. (1994) Simvolizm kak miroponimanie. [Symbolism as a World View] , Moscow, Respublika.

Frye N. (1973). Anatomy of Criticism: Four Essays .N. Y. Princeton University Press

Franklin, S. Uiddis, E. (2014) «Vse Rossii» ili «Vsya Rus'» in : Natsional'naia identichnost' v russkoi kul'ture, 12-22 Moscow, Politicheskaia entsiklopediia ["All Russia" or "All Rus", National identity in Russian culture. Moscow, Political Encyclopedia, 12-21]

Hartman G. (1980). Criticism in the Wilderness, New Haven. 6

Lotman, Y. M.(1992) Izbrannye stat'i v trekh tomakh. Tom.1. [Selected Articles in Three Volumes, Vol.1]. 203-215. Tallinn, Aleksandra 
Man P. de. (1983) Blindness and Insight. Minneapolis, 106-111

Morozov, P. (1902) Minuvshii vek. Literaturnye ocherki. [The Past Century. Literary Essays], Sankt-Peterburg, Izdanie redaktsii zhurnala «Obrazovanie»

Prokhorova, Irina (Ed.) (2017). Novoe literaturnoe obozrenie, 144 (2), 7 [New Literary Observe, 144 (2), 7]

Rozanov, V. V. (1995). O pisateliakh i pisatel'stve. [About Writers and Writership], Moscow, Respublika

Somov, O. M. (1974) O romanticheskoi poezii in: Russkie romanticheskie traktaty pervoi treti XIX v. V 2-kh t. T.2 [About Romantic Poetry, Russian romantic treatises of the first third of the XIX century,Vol. 2],545-561 Moscow, Iskusstvo

Shapir, N. (1913). Uchitel'stvo literatury, Russkaia mysl'. No 4. pp.15-37 [Teaching Literature, Russian thought No 4,15-37] Shestov, L. (1996). Sochineniia v 2-kh tomakh. [Works in 2 volumes] Vol. 2, Tomsk, Vodolei.

Turgenev, A. I. (1980) Rech' o russkoi literature, Literaturnaia kritika 1800-1820-kh godov. Moscow, Khudozhestvennaia literatura. [Talking about Russian literature, Literary criticism of the 1800-1820s. Moscow, Fiction, 44-47

Vengerov, S. A. (1919) V chem ocharovanie russkoi literatury? (rechi i vystupleniia). [What is the Charm of Russian Literature? (Speeches)], Petrograd, Svetoch

Venevitinov, D. V. (1980) O sostoianii prosveshcheniia v Rossii, Literaturnaia kritika 1800-1820-kh godov. Moscow, Khudozhestvennaia literatura [Education in Russia, Literary criticism of the 1800-1820s. Moscow, Fiction,], 278-283

Wilde O. (1966) The Complete Works , L. \& Glasgow, 1009-1060 